\title{
Akses Pasangan Usia Subur (PUS) Miskin terhadap Informasi Keluarga Berencana (KB) di Kota Yogyakarta
}

\author{
Fitriana Putri Utami ${ }^{1}$, Ratu Matahari ${ }^{1}$, dan Sri Sugiharti ${ }^{2}$ \\ ${ }^{1}$ Fakultas Kesehatan Masyarakat, Universitas Ahmad Dahlan, Yogyakarta, ${ }^{2}$ Badan \\ Kependudukan dan Keluarga Berencana Nasional (BKKBN) Perwakilan Daerah Istimewa \\ Yogyakarta
}

Korespondensi: Fitriana Putri Utami (e-mail: fitriana.utami@ikm.uad.ac.id)

\begin{abstract}
Abstrak
Upaya pemerintah dalam mengatasi tingginya laju pertumbuhan penduduk adalah dengan melaksanakan program KB (keluarga berencana). Namun, keterbatasan akses KB dialami oleh penduduk miskin dalam jumlah yang sangat besar. Salah satu faktor yang menyebabkan seorang PUS miskin tidak menjadi akseptor KB adalah terbatasnya sumber atau akses informasi terkait program KB. Penelitian ini bertujuan untuk mengetahui bagaimana akses PUS miskin di Kota Yogyakarta pada informasi terkait KB sebagai jendela awal peningkatan akseptor KB. Penelitian ini menggunakan desain mix method research, yaitu kuantitatif dan kualitatif. Penelitian kuantitatif dilakukan dengan penyebaran kuesioner pada 368 PUS miskin di Kota Yogyakarta yang dipilih menggunakan simple random sampling. Penelitian kualitatif dilakukan dengan indepth interview pada enam PUS miskin serta Focus Group Discussion (FGD) pada penyuluh KB (PKB) dan pendamping program keluarga harapan (PKH) yang dipilih secara purposive. Hasil penelitian dianalisis secara deskriptif dan content alaysis. Mayoritas PUS miskin memeroleh informasi terkait metode kontrasepsi dan program KB gratis dari bidan di puskesmas. Penyampaian informasi dalam bentuk kunjungan rumah hanya diperoleh oleh 7,3\% responden. Kendala yang dialami oleh PKB dan pendamping PKH dalam penyampaikan informasi KB adalah adanya anggapan "banyak anak banyak rezeki" serta faktor keyakinan tertentu yang melarang penggunaan kontrasepsi. Dengan demikian, pelatihan mengenai metode edukasi yang menarik bagi pendamping $\mathrm{PKH}$ dan kader kesehatan diperlukan untuk diteruskan kepada PUS miskin serta media edukasi KB sebagai pedoman.
\end{abstract}

Kata kunci: keluarga berencana; informasi KB; PUS miskin 


\title{
Poor Couples of Childbearing Age Access to Family Planning Information in Yogyakarta City
}

\begin{abstract}
The government's effort to overcome the high rate of population growth is implementing a family planning program. However, limited access to family planning is undergone by poor population in very great numbers. One factor causing poor couples of childbearing age not to become a family planning acceptor is the limited sources or access to information related to the family planning program. This study aims to find out how poor couples of childbearing age accessed information related to family planning as an initial step to increase family planning acceptors in Yogyakarta. This study used a mixed research method, i.e. quantitative and qualitative designs. Quantitative design was carried out by distributing questionnaires to 368 poor couples of childbearing age selected by using simple random sampling. Qualitative design was carried out with in-depth interviews with six poor couples of childbearing age as well as focus group discussion (FGD) on family planning officers and companions of the Program Keluarga Harapan (PKH) which were selected purposively. The results of this study were analyzed descriptively and content analysis. The majority of poor couples of childbearing age obtained information on contraceptive methods and free family planning program from midwives in primary health care. Delivered information in the form of home visits was only obtained by $7.3 \%$ of respondents. The obstacle experienced by family planning officers and $\mathrm{PKH}$ companions in delivered family planning information was the assumption that many children have lots of fortune and certain belief factors that prohibit the use of contraception. There was a need for training on interesting educational methods to $\mathrm{PKH}$ companion and health cadres to be forwarded to childbearing couples and the existence of media for family planning education as a guide.
\end{abstract}

Keywords: family planning; family planning information; poor couples of childbearing age

\section{Pendahuluan}

Indonesia merupakan salah satu negara dengan penduduk terbanyak keempat di dunia yang masih mengalami laju pertumbuhan penduduk yang tinggi. Indonesia memiliki angka kelahiran penduduk yang relatif tinggi dan menjadi permasalahan utama dalam kependudukan. Tingginya angka kelahiran akan memicu ledakan penduduk yang dapat berpengaruh pada ketersediaan pangan serta kualitas sumber daya manusia. Indonesia diprediksi akan mendapatkan "bonus demografi", yaitu bonus yang dinikmati suatu negara sebagai akibat dari besarnya proporsi penduduk produktif (rentang usia 15-64 tahun) dalam evolusi kependudukan yang dialaminya, yang diperkirakan terjadi pada 2020-2030 (Kementerian Kesehatan RI, 2015).

Salah satu upaya pemerintah untuk mencegah permasalahan tersebut adalah dengan melaksanakan program KB bagi pasangan usia subur (PUS). Program KB mulai diterapkan pemerintah sejak 1970 yang bertujuan untuk menurunkan angka kematian 
ibu, bayi, dan anak serta penanggulangan masalah kesehatan reproduksi dalam rangka pembangunan keluarga kecil berkualitas (BKKBN, 2011). Kota Yogyakarta memiliki 402.676 penduduk pada 2016 dengan laju pertumbuhan penduduk 1,22. Laju pertumbuhan penduduk yang dimiliki Kota Yogyakarta tergolong tinggi jika dibandingkan dengan kabupaten lain di DIY (Bappeda DIY, 2017; Badan Pusat Statistik, 2018). Pada 2015, 36.600 penduduk diantaranya berada di bawah garis kemiskinan (Badan Pusat Statistik, 2018).

Guna mengurangi laju pertumbuhan penduduk pada kelompok masyarakat miskin tersebut, pemerintah memberikan prioritas yang telah tertuang dalam RPJMN 2004-2009, yaitu memberikan prioritas bagi kelompok miskin menyediakan KB (Keluarga Berencana) gratis bagi masyarakat yang berasal dari kps (Keluaga Prasejahtera) dan I/KS I (keluarga sejahtera) (Bappenas RI, 2010). Namun, pemanfaatan KB gratis ini belum optimal, hal ini sesuai dengan penelitian yang menyatakan bahwa dari 2.413 PUS miskin, hanya 255 PUS saja yang mengikuti program KB Gratis (Ulfa \& Yoserizal, 2017). Hal ini mengindikasi kan bahwa masih banyak PUS miskin yang tidak mengakses alat kontrasepsi modern. Pernyataan ini didukung oleh Darwin dan Kamadi dalam Listyaningsih yang menyatakan bahwa keterbatasan akses kontrasepsi dialami oleh penduduk miskin dalam jumlah yang sangat besar (Listyaningsih dkk., 2016). Keterbatasan akses KB pada PUS miskin dapat berakibat pada sulitnya pengendalian jumlah penduduk dan tingkat kesejahteraan keluarga. Hal ini terjadi karena apabila PUS menjadi akseptor $\mathrm{KB}$, maka PUS miskin mampu mengurangi angka fertilitas dan menjaga kesehatan reproduksi, sehingga terbentuk keluarga kecil bahagia dan sejahtera (Ulfa \& Yoserizal, 2017).

Peningkatan akseptor KB sebagai anggota masyarakat yang mengikuti gerakan KB dengan melaksanakan penggunaan alat kontrasepsimampu mempercepat pencapaian keberhasilan pelayanan KB. Salah satu faktor yang menyebabkan seorang PUS tidak menjadi akseptor KB adalah sumber atau akses informasi terkait program KB. Informasi kesehatan termasuk informasi mengenai $\mathrm{KB}$ sangat penting dalam merubah perilaku individu dalam kesehatan. Rendahnya National Readingness Index menunjukan bahwa masyarakat Indonesia mempunyai kebiasaan membaca dan pencarian informasi yang rendah. Rendahnya tingkat pendapatan individu memperburuk kebiasaan dalam pencarian informasi tersebut secara mandiri (Lette, 2018).

Informasi tentang efek samping KB di D.I. Yogyakarta yang diterima oleh kelompok masyarakat yang tidak bersekolah dan berada di kuintil 1 hanya sekitar 24,1\% dan 25,3\%. Akseptor yang menerima informasi terkait efek samping alat kontrasepsi melalui petugas $\mathrm{KB}$ dan $\mathrm{KB}$ safari juga masih menunjukan persentase yang rendah, yaitu masing-masing $32,4 \%$ dan $25,5 \%$. Pemberian konseling dan KIE program KB bagi KPS dan KS-I pada pelayanan KB secara massal, seperti pada momentum KB, berjalan kurang efektif. Hal ini terlihat dari banyaknya akseptor KB miskin di D.I. Yogyakarta yang mengeluhkan kurangnya pemahaman pada jenis kontrasepsi yang mereka gunakan, padahal akseptor KB miskin mengaku telah menerima informasi tetang KB sebelumnya (Bappenas RI, 2010).

Stakeholder kesehatan, seperti bidan dan dokter serta kader, memiliki peran penting dalam penyampaian informasi kesehatan kepada masyarakat. Untuk informasi terkait KB 
guna meningkatkan akseptor $\mathrm{KB}$, maka perlu adanya dukungan penyampaian komunikasi informasi edukasi (KIE) yang mumpuni, dalam hal ini penyuluh KB (PKB) memiliki peran yang sangat penting. Permasalahan yang kerap ditemui oleh PKB adalah kurangnya pemahaman masyarakat tentang KB dengan baik karena kurangnya informasi yang didapat. Hal ini membuat penyuluhan mengenai KB menjadi ujung tombak pengelola KB di lini lapangan (Nurmahdalena, 2016). Proses peningkatan pengetahuan serta pemberdayaan PUS miskin selaku warga prasejahtera di Kota Yogyakarta tidak hanya dilakukan oleh Dinas Kependudukan dan Keluarga Berencana Kota Yogyakarta dan Kantor Perwakilan BKKBN DIY, tetapi juga didukung oleh Dinas Sosial melalui kegiatan pendampingan Program Keluarga Harapan (PKH). Oleh sebab itu, penelitian ini bertujuan untuk mengetahui bagaimana akses PUS miskin di Kota Yogyakarta pada informasi terkait KB berperan sebagai jendela awal dalam peningkatan akseptor KB.

\section{Metode Penelitian}

Penelitian ini menggunakan desain mix method research, yaitu kuantitatif dan kualitatif. Responden kuantitatif dalam penelitian ini adalah 368 PUS di tiga wilayah kecamatan dengan jumlah keluarga tertinggi penerima jaminan perlindungan sosial berdasarkan data Keluarga Sasaran Jaminan Perlindungan Sosial Kota Yogyakarta, yaitu kecamatan Umbulharjo, Kecamatan Mergangsan, dan Kecamatan Tegalrejo. Sampel penelitian dipilih menggunakan teknik simple random sampling yang dilakukan pada data warga prasejahtera dan sejahtera I berdasarkan data PUS dari Dinas Sosial Kota
Yogyakarta. Pengambilan data kuantitatif dilakukan dengan wawancara door to door ke rumah responden dengan menggunakan instrumen kuesioner. Penelitian kualitatif dilakukan untuk memperkuat hasil yang didapat dari desain kuantitatif. Subjek penelitian kualitatif adalah tiga PUS yang memutuskan menerapkan program KB dan tiga PUS tidak menerapkan KB, serta enam orang PKB dan enam orang pendaming $\mathrm{PKH}$ yang dipilih secara purposive. Pengambilan data untuk PUS dilakukan menggunakan indepth interview, sedangkan pengambilan data untuk PKB dan pendamping $\mathrm{PKH}$ dilakukan dengan focus group discussion (FGD). Penelitian ini dilaksanakan pada September - November 2018. Analisis data kuantitatif yang didapat menggunakan descriptive analysis, sedangkan data kualitatif dikaji dengan menggunakan content analysis.

\section{Hasil dan Pembahasan}

Hasil

Stakeholder KB memiliki peran untuk menyampaikan KIE terkait program KB kepada PUS miskin di Kota Yogyakarta. Salah satu dukungan yang diberikan oleh stakeholder KB kepada PUS miskin adalah penyampaian $\mathrm{KIE}$ mengenai berbagai jenis metode KB. Penyampaian informasi ini menjadi dasar pengetahuan yang dimiliki PUS dalam menentukan jenis metode kontrasepsi yang akan digunakannya. Dalam penelitian ini, dari 368 responden yang terlibat, 247 responden $(67,1 \%)$ menggunakan alat kontrasepsi (alokon) dan 121 responden (32,9\%) tidak menggunakan alat kontrasepsi. Persentase responden yang mengakses alat kontrasepsi dapat dilihat pada Gambar 1. 


\title{
Penggunaan alat kontrasepsi
}

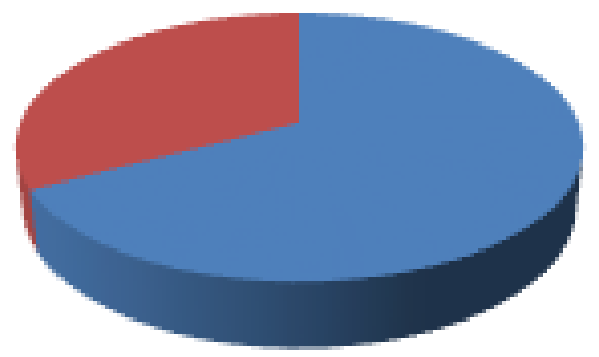

\author{
menggunakan
}

alokon

Gambar 1. Persentase Penggunaan Alat Kontrasepsi

Infomasi mengenai KB peneliti dapatkan dengan bertanya kepada responden apakah responden mengetahui beberapa jenis alat kontrasepsi yang peneliti sebutkan. Jika responden mengetahui alat kontrasepsi tersebut, maka peneliti memberikan pertanyaan lanjutan tentang sumber informasi alat kontrasepsi tersebut. Berdasarkan wawancara yang dilakukan pada seluruh responden,alat kontrasepsi yang paling banyak diketahui oleh responden adalah pil KB, yaitu diketahui oleh 364 responden
$(98,9 \%)$. Selain itu, mayoritas responden mendapatkan informasi mengenai alat kontrasepsi dari bidan puskesmas. Selain bidan puskesmas, stakeholder KB yang juga aktif menyampaikan informasi mengenai alat kontrasepsi adalah bidan swasta dan kader PKK. Informasi mengenai alat kontrasepsi yang paling sedikit didapat oleh responden berasal dari penyuluh KB. Persentase informasi terkait alat kontrasepsi yang diterima oleh responden disajikan pada Tabel 1.

Tabel 1. Distribusi Sumber Informasi Terkait Metode Kontrasepsi

\begin{tabular}{|c|c|c|}
\hline Variabel & Jumlah Responden & Persentase \\
\hline \multicolumn{3}{|c|}{$\begin{array}{l}\text { Mengetahui Metode Operasi Wanita } \\
\text { (MOW) }\end{array}$} \\
\hline Tidak & 102 & $27,7 \%$ \\
\hline Ya & 266 & $72,3 \%$ \\
\hline \multicolumn{3}{|l|}{ Sumber Informasi MOW } \\
\hline Bidan Praktik Swasta & 15 & $5,6 \%$ \\
\hline Bidan Puskesmas & 102 & $38,3 \%$ \\
\hline Dokter & 8 & $3,0 \%$ \\
\hline Kader KB & 12 & $4,5 \%$ \\
\hline Kader PKK & 52 & $19,5 \%$ \\
\hline Kader Posyandu & 15 & $5,6 \%$ \\
\hline Keluarga & 10 & $3,8 \%$ \\
\hline Media & 10 & $3,8 \%$ \\
\hline
\end{tabular}


Fitriana Putri Utami, Ratu Matahari, dan Sri Sugiharti

\begin{tabular}{|c|c|c|}
\hline Petugas KB & 1 & $0,4 \%$ \\
\hline Teman & 20 & $7,5 \%$ \\
\hline Tetangga & 21 & $7,9 \%$ \\
\hline \multicolumn{3}{|c|}{ Mengetahui Metode Operasi Pria (MOP) } \\
\hline Tidak & 142 & $38,6 \%$ \\
\hline Ya & 226 & $61,4 \%$ \\
\hline \multicolumn{3}{|l|}{ Sumber Informasi MOP } \\
\hline Bidan Praktik Swasta & 13 & $5,8 \%$ \\
\hline Bidan Puskesmas & 99 & $43,8 \%$ \\
\hline Buku KIA & 5 & $2,2 \%$ \\
\hline Dokter & 4 & $1,8 \%$ \\
\hline Internet & 5 & $2,2 \%$ \\
\hline Kader KB & 7 & $3,1 \%$ \\
\hline Kader PKK & 30 & $13,3 \%$ \\
\hline Kader Posyandu & 17 & $7,5 \%$ \\
\hline Keluarga & 3 & $1,3 \%$ \\
\hline Sekolah & 2 & $0,9 \%$ \\
\hline Televisi & 3 & $1,3 \%$ \\
\hline Teman & 14 & $6,2 \%$ \\
\hline Tetangga & 24 & $10,6 \%$ \\
\hline \multicolumn{3}{|c|}{ Mengetahui intrauterine device (IUD) } \\
\hline Tidak & 13 & $3,5 \%$ \\
\hline $\mathrm{Ya}$ & 355 & $96,5 \%$ \\
\hline \multicolumn{3}{|l|}{ Sumber Informasi IUD } \\
\hline Bidan Praktik Swasta & 38 & $10,7 \%$ \\
\hline Bidan Puskesmas & 210 & $59,2 \%$ \\
\hline BKKBN & 2 & $0,6 \%$ \\
\hline Dokter & 9 & $2,5 \%$ \\
\hline Kader KB & 6 & $1,7 \%$ \\
\hline Kader PKK & 28 & $7,9 \%$ \\
\hline Kader Posyandu & 13 & $3,7 \%$ \\
\hline Keluarga & 4 & $1,1 \%$ \\
\hline Sekolah & 1 & $0,3 \%$ \\
\hline Teman & 15 & $4,2 \%$ \\
\hline Tetangga & 28 & $7,9 \%$ \\
\hline Televisi & 1 & $0,3 \%$ \\
\hline \multicolumn{3}{|l|}{ Mengetahui Injeksi } \\
\hline Tidak & 7 & $1,9 \%$ \\
\hline $\mathrm{Ya}$ & 361 & $98,1 \%$ \\
\hline \multicolumn{3}{|l|}{ Sumber Informasi Injeksi } \\
\hline Bidan Praktik Swasta & 51 & $14,1 \%$ \\
\hline Bidan Puskesmas & 214 & $59,3 \%$ \\
\hline Bimbingan KUA & 1 & $0,3 \%$ \\
\hline Dokter & 5 & $1,4 \%$ \\
\hline
\end{tabular}


Akses Pasangan Usia Subur (PUS) Miskin terhadap Informasi Keluarga Berencana (KB) di Kota Yogyakarta

\begin{tabular}{|c|c|c|}
\hline Kader KB & 4 & $1,1 \%$ \\
\hline Kader PKK & 23 & $6,4 \%$ \\
\hline Kader Posyandu & 20 & $5,5 \%$ \\
\hline Keluarga & 5 & $1,4 \%$ \\
\hline Sekolah & 1 & $0,3 \%$ \\
\hline Teman & 14 & $3,9 \%$ \\
\hline Tetangga & 23 & $6,4 \%$ \\
\hline \multicolumn{3}{|l|}{ Mengetahui Implan } \\
\hline Tidak & 26 & $7,1 \%$ \\
\hline Ya & 342 & $92,9 \%$ \\
\hline \multicolumn{3}{|l|}{ Sumber Informasi Implan } \\
\hline Bidan Praktik Swasta & 33 & $9,6 \%$ \\
\hline Bidan Puskesmas & 188 & $55,0 \%$ \\
\hline Bimbingan KUA & 1 & $0,3 \%$ \\
\hline Buku KIA & 2 & $0,6 \%$ \\
\hline Dokter & 5 & $1,5 \%$ \\
\hline Kader KB & 3 & $0,9 \%$ \\
\hline Kader PKK & 19 & $5,6 \%$ \\
\hline Kader Posyandu & 16 & $4,7 \%$ \\
\hline Keluarga & 11 & $3,2 \%$ \\
\hline Sekolah & 1 & $0,3 \%$ \\
\hline Teman & 36 & $10,5 \%$ \\
\hline Tetangga & 27 & $7,9 \%$ \\
\hline \multicolumn{3}{|l|}{ Mengetahui Pil KB } \\
\hline Tidak & 4 & $1,1 \%$ \\
\hline Ya & 364 & $98,9 \%$ \\
\hline \multicolumn{3}{|l|}{ Sumber Informasi Pil KB } \\
\hline Bidan Praktik Swasta & 51 & $14,0 \%$ \\
\hline Bidan Puskesmas & 205 & $56,3 \%$ \\
\hline Bimbingan KUA & 1 & $0,3 \%$ \\
\hline Buku KIA & 2 & $0,5 \%$ \\
\hline Dokter & 3 & $0,8 \%$ \\
\hline Kader KB & 4 & $1,1 \%$ \\
\hline Kader PKK & 21 & $5,8 \%$ \\
\hline Kader Posyandu & 16 & $4,4 \%$ \\
\hline Keluarga & 6 & $1,6 \%$ \\
\hline Koran & 1 & $0,3 \%$ \\
\hline Sekolah & 1 & $0,3 \%$ \\
\hline Televisi & 1 & $0,3 \%$ \\
\hline Teman & 25 & $6,9 \%$ \\
\hline Tetangga & 27 & $7,4 \%$ \\
\hline \multicolumn{3}{|l|}{ Mengetahui Kondom } \\
\hline Tidak & 10 & $2,7 \%$ \\
\hline Ya & 358 & $97,3 \%$ \\
\hline
\end{tabular}




\begin{tabular}{lrr}
\hline Sumber Informasi Kondom & & \\
Bidan Praktik Swasta & 23 & $6,4 \%$ \\
Bidan Puskesmas & 137 & $38,3 \%$ \\
Bimbingan KUA & 1 & $0,3 \%$ \\
Buku KIA & 1 & $0,3 \%$ \\
Dokter & 3 & $0,8 \%$ \\
Internet & 1 & $0,3 \%$ \\
Kader KB & 5 & $1,4 \%$ \\
Kader PKK & 16 & $4,5 \%$ \\
Kader Posyandu & 14 & $3,9 \%$ \\
Keluarga & 18 & $5,0 \%$ \\
Media Cetak & 7 & $2,0 \%$ \\
Televisi & 19 & $5,3 \%$ \\
Teman & 74 & $20,7 \%$ \\
Tetangga & 74 & $10,9 \%$ \\
\hline Total Responden & 39 & $100,0 \%$ \\
\hline
\end{tabular}

Pemerintah Kota Yogyakarta memiliki kebijakan program KB gratis. Program ini ditujukan bagi PUS yang memiliki Jaminan Kesehatan Nasional (JKN). Selain itu, PUS yang memiliki KTP Kota Yogyakarta juga memiliki hak untuk mengakses $\mathrm{KB}$ gratis di seluruh puskesmas di wilayah Kota Yogyakarta. Terkait hal ini, peneliti menemukan bahwa 188 responden $(76,1 \%)$ mengetahui adanya program KB gratis, sisanya $(23,9 \%)$ mengaku tidak mengetahui adanya program KB gratis. Mayoritas responden menerima informasi mengenai program KB gratis dari bidan puskesmas $(64,4 \%)$ kader posyandu $(14,9 \%)$, dan kader PKK (9,6\%). Informasi mengenai program KB gratis paling sedikit diperoleh dari dokter $(0,5 \%)$.

Kunjungan stakeholder KB ke rumah responden sebagai akseptor KB dalam enam bulan terakhir dinilai masih minim, yaitu hanya 18 responden $(7,3 \%)$ yang pernah mendapat kunjungan rumah. Dari 18 responden yang pernah mendapat kunjungan ini, hanya satu responden $(5,6 \%)$ yang pernah dikunjungi oleh penyuluh KB/PLKB, 17 responden yang lain $(84,4 \%)$ dikunjungi oleh kader kesehatan.
Kunjungan rumah yang hanya diterima oleh 18 responden ini didominasi oleh kegiatan pendataan terkait program KB, pendataan ini diterima oleh 17 responden (94,4\%). Kegiatan lain adalah stakeholder KB mengingatkan responden untuk menerapkan program KB yang diterima oleh 7 responden $(38,9 \%)$. Selain dua kegiatan tersebut, kunjungan rumah juga berisi penyampaian informasi tentang $\mathrm{KB}$, yaitu informasi terkait alat kontrasepsi dan efek samping KB. Informasi mengenai alat kontrasepsi diterima oleh delapan responden $(44,4 \%)$ dan informasi tentang efek samping diterima oleh 15 responden (83,3\%).

Hasil analisis dari kegiatan FGD pada PKB didapatkan bahwa tugas pokok PKB adalah berkaitan dengan pengelolaan, penggerakan, pemberdayaan, dan kemitraan melalui pendekatan sepuluh langkah penyuluhan KB yang meliputi kegiatan pendataan, pemetaan, pembentukan kelompok kegiatan (POKTAN), pemantapan, KIE khususnya konseling, grup pelopor, pelayanan, pembinaan peserta (keberlangsungan akseptor), serta evaluasi program. Hal tersebut terlihat dalam kutipan wawancara di bawah ini. 
“......Dalam melaksanakan tugas pokok $P K B$, dilakukan pendekatan formal melalui 10 langkah penyuluh KB yaitu pendataan, pemetaan, pembentukan kesepakatan, pemantapan dengan membuat SK, KIE (konseling), grup pelopor, pelayanan, pembinaan peserta untuk melihat keberlangsungan akseptor, dan evaluasi....." (YLS, FGD, PKB 10 tahun)

PKB mengungkapkan bahwa salah satu permasalahan dalam program KB di Kota Yogyakarta adalah jumlah unmet need (kebutuhan yang tidak terpenuhi) masih tinggi. Menghadapi hal ini, PKB menerapkan beberapa usaha untuk mengatasi hal tersebut seperti (1) Pelaksanaan KIE pada PUS unmet need melalui POKTAN; (2) Penjaringan akseptor melalui kegiatan bakti sosial KB di beberapa rumah sakit rekanan BKKBN; (3) Pelayanan KB menggunakan KTP; dan (4) BPJS untuk pelayanan MKJP (IUD, MOW, dan MOP). Upaya-upaya tersebut tertuang dalam kutipan FGD di bawah ini.

“........Kota Yogyakarta berada di kuadran 3, yaitu capaian $K B$ rendah tetapi kehamilan juga rendah. Beberapa kegiatan sudah kami lakukan misalnya dengan memberikan KIE kepada PUS unmet need melalui POKTAN dan Baksos di rumah sakit $H L, L H$, dan PA sebanyak $4 x$ setiap tahunnya...." (TRY, FGD, PKB 6 Tahun)

“...Di Kota Yogyakarta ini ya jumlah PUS meningkat tetapi yang KB stagnant berarti PAnya menurun. ada beberapa upaya yang kita lakukan untuk menjawab masalah tersebut yaitu dengan melakukan baksos 5 kali tiap tahun, memberikan pelayanan KB pada akseptor dengan menggunakan
KTP, BPJS untuk MKJP tetapi hal tersebut juga menimbulkan masalah yaitu kami kesulitan melakukan rujukan pada metode KB MOW yang dilakukan pada fasyankes yang bukan FKTP, kami juga melakukan KIE POKTAN melalui konseling akseptor MKJP di Puskesmas....." (YLS, FGD, PKB 10 tahun)

Dalam penelitian ini diketahui juga bahwa PKB memiliki kesulitan dalam memberikan pemahaman terkait metode kontrasepsi modern pada peserta KB alami. Untuk mengatasi masalah tersebut, para PKB juga mendatangkan akseptor KB metode modern pada pelaksanaan kegiatan KIE untuk memberikan testimoni. Hal serupa juga dilakukan pada saat melakukan edukasi KB pada kelompok laki-laki. Hal tersebut dibuktikan dari petikan FGD sebagai berikut.

“....untuk metode kontrasepsi MOP kami mendatangkan testimony untukmemotivasi para pria mau menggunakan KB...misalnya seperti di kecamatan Mergangsan itu juga PUS MUPAR sulit untuk diberikan pemahaman terkait metode kontrasepsi yang lain padahal PUS MUPARnya juga tinggi..." (AGS, FGD, PKB 8 tahun)

Berdasarkan hasil wawancara mendalam dengan PUS miskin yang mengakses alat kontrasepsi modern, salah satu informan mengaku bahwa pendampingan program KB dari PKB terakhir didapatkan pada 2005 dan informasi mengenai metode kontrasepsi diperoleh dari bidan puskesmas. Sementara itu, informan yang lain menyatakan bahwa mereka pernah mendapatkan sosialisasi KB dari PKB. Petikan wawancara informan dapat dilihat sebagai berikut. 
"Selama ini gak ada pendampingan KB dari PKB. Penyuluhan KB didapatkan di puskesmas sama bidan soalnya pendampingan dari PKB terakhir antara tahun 2004-2005." (STT, Indepth, PUS KB, 40)

"Sosialisasi tentang KB pernah dikasih ke kader KB di masing-masing RT. Yang memberikan PKB kecamatan sini... Kalau yang buat saya pilih pake KB CO (kondom) karena hasil saya konseling sama bidan puskesmas." (NN, Indepth, PUS KB, 37)

Hasil wawancara mendalam yang dilakukan pada PUS yang tidak menerapkan program KB menunjukkan bahwa mereka belum pernah mendapatkan pendampingan dari PKB. Alasan yang menyebabkan mereka memilih untuk tidak menggunakan alat kontrasepsi saat penelitian ini berlangsung adalah karena rasa takut terhadap efek samping dan adanya keinginan untuk memiliki anak lagi. Hal tersebut terlihat dari petikan wawancara sebagai berikut.

"Gak ada pendampingan KB dari PKB. Pendampingan yang saya dapet cuman dari PKH tentang penyuluhan cara mendidik anak sama bikin usaha...... dulu pernah pakai KB suntik yang tiga bulanan, cuman pakai 6 kali aja tapi. Tapi terus mens saya ga berhenti sama pusing banget. Akhirnya saya stop...... mau pakai IUD tapi takut banget, kakak ipar pernah hilang IUDnya soalnya, jadi ngeri." (MTN, Indepth, PUS non-KB, 45)

"Penyuluhan KB gak pernah dapet saya. Dapetnya penyuluhan tentang didik anak, atur keuangan keluarga, jaga kebersihan diri sendiri sama keluarga aja. PKH saya yang kasih......... Saya gak pernah pake $K B$ blas dari habis nikah dulu soalnya saya masih pengen punya anak lagi jadi ya gak pernah pasang KB" (SPH, Indepth, PUS non-KB, 40)

Berdasarkan penjelasan dari PUS miskin, pendampingan yang diterimanya adalah berasal dari pendamping $\mathrm{PKH}$. Peneliti mengonfirmasi kepada pendamping $\mathrm{PKH}$ mengenai kemungkinan adanya penyebaran informasi kesehatan, khususnya terkait KB yang dilakukan oleh $\mathrm{PKH}$. Berdasarkan hasil FGD, pendamping $\mathrm{PKH}$ sendiri memiliki tugas pokok, seperti memberikan pendidikan pembinaan keluarga dan kesehatan melalui program family development system (FDS), pendampingan kehadiran anak di posyandu, pendampingan ibu hamil di puskesmas, verifikasi ke pelayanan kesehatan terkait gizi anak rendah, dan pencatatan serta pelaporan. Berdasarkan hasil FGD tersebut, PKH juga bersinergi dengan PKB dalam menyukseskan program KB di Kota Yogyakarta. Pendamping $\mathrm{PKH}$ meyakini bahwa semua masyarakat dari berbagai kalangan ekonomi berhak untuk mendapatkan akses informasi dan pelayanan KB sesuai kebutuhan mereka. Namun tidak dipungkiri bahwa masih banyak PUS miskin yang beranggapan bahwa memiliki banyak anak akan mendatangkan banyak rezeki, sehingga informasi mengenai KB menjadi sulit untuk diterima. Penyampaian informasi mengenai alat kontrasepsi pria juga sulit untuk dilakukan karena mayoritas peserta yang datang dalam kegiatan pendampingan adalah ibu-ibu. Hal ini tertuang dalam kutipan wawancara sebagai berikut.

“.....Kami melakukan pendampingan pendidikan dan kesehatan, kehadiran anak di posyandu, dan pemantauan 
kehadiran ibu hamil di puskesmas, ....kami juga melakukan pelaporan bulanan dalam form yang ada.... Pertemuan kelompok mayoritas itu yang datang ibu-ibu jadi untuk promosi atau edukasi MOP sulit dilakukan ..." (SPR, FGD, PKH 8 tahun)

“.....Kami mendapatkan 20 akseptor KB..tetapi ada beberapa keluhan yang dirasakan oleh masyarakat terhadap $K B$ yaitu adanya kegagalan KB suntik, komplikasi penyakit, dan berkaitan dengan agama/keyakinan penduduk yang tidak mau berKB..misalnya yang bercadar..." (MTA, FGD, PKH 8 tahun)

Pendamping PKH menjelaskan bahwa salah satu hambatan dalam menyampaikan informasi KB adalah adanya keyakinan atau agama yang membuat anggota $\mathrm{PKH}$ tidak mau menerapkan program $\mathrm{KB}$, sehingga upaya ini sulit dilakukan untuk memotivasi mereka. Untuk mengatasi permasalahan tersebut, seluruh pendamping $\mathrm{PKH}$ mengharapkan adanya perbaikan sistem kerja program KB, yaitu penyediaan praktisi (tim KB BKKBN) yang memberikan edukasi melalui metode permainan (games), sehingga menarik perhatian peserta, penyuluhan KB yang beragam, serta harapan PKB melakukan kunjungan kepada masyarakat yang belum menerapkan program KB, terutama pada anggota masyarakat dengan keyakinan atau agama tertentu. Harapan ini tertuang dalam kutipan FGD sebagai berikut.

“....mbok siapa tau ada praktisi atau dari $B K K B N$ memberikan penyuluhan info tentang KB dibuat menarik pakai games games gitu jadinya peserta gak bosen.... trus kami dikasih bukunya atau apa gitu kayak lembar balik biar jadi pegangan kami untuk ngomong tentang KB ..." (SPR, FGD, PKH 8 tahun)

"...Perlu dilakukan sosialisasi KB oleh PKB dan fasilitasi KB...." (BN, FGD, PKH 8 tahun)

\section{Pembahasan}

Penggunaan kontrasepsi yang didasari oleh pemahaman serta kesadaran yang baik akan mampu meningkatkan jumlah peserta KB aktif (Bappenas RI, 2010). Komunikasi, Informasi, dan Edukasi (KIE) KB adalah nama yang dikenal dalam proses pemberian informasi program KB. Penyebaran informasi ini dilakukan melalui proses komunikasi untuk mempercepat proses perubahan perilaku individu dalam masyarakat (Mahmudah \& Indrawati, 2015). Pemberian KIE bisa dilakukan melalui metode pendidikan komunitas atau disebut sebagai community education. Sebuah kajian ilmiah mengenai KIE program KB menjelaskan bahwa pendekatan community education merupakan sebuah pendekatan yang positif dalam mentransfer pengetahuan KB dan didukung media promosi, seperti media massa, situs jejaring (website), penjelasan menggunakan selebaran (leaflet) atau lembar balik, dan juga pendekatan secara interpersonal (Sharma, Frederiksen, Malcolm, Rollison, \& Carter, 2018). Informasi KB yang diterima dengan baik oleh akseptor KB akan membantu meningkatkan kewaspadaan dalam menghadapi efek samping dan mengurangi putus-pakai pada pemakaian alat kontrasepsi (Bappenas RI, 2010).

Pemberian informasi oleh penyuluh kesehatan kepada masyarakat dapat meningkatkan partisipasi masyarakat dalam melaksanakan program kesehatan tersebut. 
Seorang ibu yang mendapat informasi mengenai $\mathrm{KB}$ akan lebih mudah dalam memutuskan penggunaan alat kontrasepsi. Bahkan seorang wanita yang sebelumnya tidak terpikir untuk menggunakan alat kontrasepsi dapat menemukan arti pentingnya mengikuti program KB melalui konseling dengan penyuluh kesehatan (Lette, 2018). Konseling yang dilakukan pasca melahirkan bahkan memiliki dampak moderat pada penggunaan kontrasepsi yang efektif bagi wanita postpartum (Reyes-Lacalle et al., 2020). Dukungan melalui pemberian informasi oleh penyuluh kesehatan dapat diwujudkan melalui kegiatan penyuluhan, pembimbingan dan pembinaan, serta pelatihan. Dukungan dari penyuluh kesehatan antara lain berasal dari penyuluh KB (PKB), bidan, perawat, dokter, dan sebagainya (Sulikhah, Nugroho, \& Dharmawan, 2017).

Hasil penelitian ini menunjukkan bahwa informasi mengenai metode kontrasepsi paling banyak diperoleh dari bidan, hal ini sama dengan hasil yang didapat oleh penelitian milik Lette yang menyatakan bahwa KIE yang dilakukan oleh para bidan di puskesmas sangat efektif dalam memengaruhi ibu menjadi akseptor KB. Hal ini diperkuat oleh pernyataan dari penyuluh lapangan KB bahwa bidan-bidan selain memberikan pelayanan fisik, mereka juga mempunyai kewenangan untuk melaksanakan KIE (Lette, 2018). KIE KB merupakan aspek penting dalam pelayanan KB. Dengan melakukan KIE berarti bidan membantu calon akseptor untuk dapat menentukan jenis kontrasepsi yang terbaik untuk dirinya dan membantu akseptor KB dalam menggunakan kontrasepsinya lebih lama dan meningkatkan keberhasilan KB (Kusumastuti dkk., 2012).

PKB berperan penting dalam pengendalian pertumbuhan penduduk dengan memberikan pemahaman berupa informasi terkait KB kepada masyarakat. Jika dilihat dari fungsi ini, maka peran PKB belum berjalan dengan optimal mengingat hanya sedikit responden yang mendapatkan informasi KB dari PKB. Hal ini cukup disayangkan mengingat program KB bukan hanya terpaku pada penurunan angka kelahiran tetapi juga membuat para akseptornya menjadi lebih sejahtera guna kemajuan taraf hidup yang lebih layak agar menunjang perekonomian keluarga (Nurmahdalena, 2016).

Tingkat sosial ekonomi yang rendah pada PUS merupakan salah satu hambatan dalam menyampaikan informasi terkait KB disamping faktor lain, seperti pengetahuan, pendidikan, usia, pengalaman, dan pekerjaan. Penyampaian informasi di kalangan PUS miskin juga sering diiringi oleh hambatan yang bersifat teknis, seperti minimnya tempat atau ruangan untuk melaksanakan sosialisasi program KB. Hambatan yang tidak kalah sering ditemui adalah pola pikir masyarakat yang tidak memperbolehkan penggunaan alat kontrasepsi (Wowiling, Pantow, \& Waleleng, 2015).

Faktor penentu penggunaan kontrasepsi modern di masyarakat adalah tidak adanya pola pikir negatif pada alat kontrasepsi tersebut. Berdasarkan hal ini, faktor penentu utama yang teridentifikasi adalah perlunya intervensi praktis berupa pemberian informasi KB pada pria dan wanita yang lebih berfokus pada manfaat layanan kontrasepsi modern untuk membantu menghilangkan kesalahpahaman mitos dan pikiran negatif tentang kontrasepsi modern serta mengurangi ketidaksetujuan pria pada penggunaan alat kontrasepsi (Asiedu et al., 2020). Penelitian ini menunjukkan bahwa adanya harapan agar dilakukan pendampingan khusus berupa kunjungan ke rumah PUS miskin yang tidak 
menerapkan program KB dan terutama yang juga tidak mendukung program KB karena adanya anggapan kepercayaan atau agama tertentu. Hal ini disebabkan karena KB tidak hanya berkaitan dengan demografi dan klinis, tetapi juga mempunyai dimensi sosial budaya dan agama, khususnya perubahan sistem nilai dan norma masyarakat.

Informasi mengenai KB akan lebih lama ditangkap dan dipahami oleh masyarakat dengan tingkat pendidikan dan kesejahteraan rendah. Kondisi tersebut diperburuk dengan adanya pengaruh kultur dan kebiasaan yang ada di masyarakat, seperti norma-norma atau kepercayaan tertentu, sehingga upaya untuk meningkatkan pemahaman berupa promosi dan KIE pada kelompok tertentu ini berbeda jika dibandingkan dengan upaya yang ditujukan untuk masyarakat dengan tingkat pendidikan dan kesejahteraan yang lebih baik. Dengan demikian, pendekatan KIE yang lebih inovatif diperlukan untuk mengajak PUS miskin aktif untuk menerapkan program KB. Pendekatan tersebut dapat diawali dengan melakukan pemetaan pada permasalahan dalam melakukan KIE pada kelompok masyarakat KPS dan KSI, kemudian dilanjutkan dengan pembuatan pedoman teknis pelaksanaan KIE pada kelompok masyarakat tersebut. Keberhasilan pendekatan proses KIE ini sangat bergantung pada skill lapangan stakleholder KB, sehingga dibutuhkan adanya upaya peningkatakan skill dan kompetensi SDM tenaga lini lapangan dalam melakukan promosi dan KIE KB serta pelatihan bagi petugas kesehatan di sarana penyedia layanan KB (Bappenas RI, 2010).

\section{Kesimpulan dan Saran}

Responden dalam penelitian ini 67,1\% diantaranya adalan akseptor KB. Pil KB merupakan alat kontrasepsi yang paling banyak diketahui oleh responden, yaitu 364 responden (98,9\%). Sumber informasi yang paling banyak memberikan informasi mengenai alat kontrasepsi pada responden adalah bidan puskesmas. Selain itu, stakeholder KB yang juga aktif menyampaikan informasi mengenai alat kontrasepsi adalah bidan swasta dan kader PKK. Sementara itu, sumber informasi yang paling sedikit didapatkan responden adalah penyuluh KB.

PKB menemui beberapa masalah terkait $K B$ di PUS miskin, antara lain tingginya angka unmet need dan sulitnya memberikan pemahaman metode kontrasepsi modern pada peserta KB alami. Upaya yang dilakukan PKB dalam menyelesaikan masalah tersebut adalah dengan melaksanakan KIE pada PUS unmet need melalui POKTAN serta KIE dengan mendatangkan testimoni akseptor KB modern. PKH bersinergi dengan PKB dalam menyelesaikan masalah program KB. Hambatan yang ditemui adalah adanya anggapan "banyak anak banyak rejeki" dan keyakinan agama yang melarang menggunakan KB. Berdasarkan hal ini, perlu adanya pelatihan kepada stakeholder KB di lapangan, seperti $\mathrm{PKB}$, pendamping $\mathrm{PKH}$, kader kesehatan dari praktisi BKKBN terkait edukasi KB dengan metode yang menarik perhatian peserta serta adanya media edukasi yang dapat digunakan sebagai panduan bagi pendamping $\mathrm{PKH}$ dalam memberikan informasi KB pada PUS miskin.

\section{Ucapan Terima Kasih}

Peneliti mengucapkan terima kasih kepada BKKBN Pusat Republik Indonesia atas dana yang telah diberikan, sehingga penelitian ini dapat terlaksana dengan baik. Peneliti juga mengucapkan terima kasih 
kepada Perwakilan BKKBN D.I. Yogyakarta, Dinas Sosial Kota Yogyakarta dan Universitas Ahmad Dahlan atas dukungan moral serta informasi yang telah diberikan.

\section{Daftar Pustaka}

Asiedu, A., Asare, B. Y. A., Dwumfour-Asare, B., Baafi, D., Adam, A. R., Aryee, S. E., \& Ganle, J. K. (2020). Determinants of modern contraceptive use: A crosssectional study among market women in the Ashiaman Municipality of Ghana. International Journal of Africa Nursing Sciences, 12(100184), 1-8. https://doi. org/10.1016/j.ijans.2019.100184.

Badan Pusat Statistik. (2018). Jumlah Penduduk Menurut Kabupaten/ Kota di D.I Yogyakarta (Jiwa). Retrieved from https://yogyakarta.bps.go.id/ dynamictable/2017/08/02/32/jumlahpenduduk-menurut-kabupaten-kota-di-d-iyogyakarta-jiwa-.html.

Bappeda DIY. (2017). Pertumbuhan Penduduk

Data Vertikal Badan Pusat Statistik. Retrieved from http://bappeda.jogjaprov. go.id/dataku/data_dasar/index/370pertumbuhan-penduduk?id_skpd=29.

Bappenas RI. (2010). Laporan Akhir Evaluasi Pelayanan Keluarga Berencana bagi Masyarakat Miskin (Keluarga Prasejahtera I KPS dan Keluarga Sejahtera-I/ KS-I).

BKKBN. (2011). Analisis Lanjut 2011 Faktor Faktor yang Mempengaruhi Penggunaan MKJP di Enam Wilayah Indonesia. Jakarta. Kementerian Kesehatan RI. (2015). Buku Ajar Kesehatan Ibu dan Anak. Jakarta: Pusat Pendidikan dan Pelatihan Tenaga Kesehatan.

Kusumastuti, Purnami, C. T., \& Tjondrorini. (2012). Analisis Faktor-Faktor yang Berhubungan dengan Perilaku Pelayanan
Kontrasepsi oleh Bidan di Kabupaten Kebumen. Jurnal IImiah Kesehatan Keperawatan, 11(2), 91-103.

Lette, A. R. (2018). Sumber Informasi dan Peran Signifikan Others dalam Program Keluarga Berencana di Klinik Pratama Citra Husada Kupang. Jurnal Publikasi Kesehatan Masyarakat Indonesia, 5(1), 25-34. https://doi.org/https://dx.doi. org/10.20527/jpkmi.vsi1.4998.

Listyaningsih, U., Sumini, S., \& Satiti, S. (2016). Unmet Need: Konsep Yang Masih Perlu Diperdebatkan. Populasi, 24(1), 7290. https://doi.org/10.22146/jp.23696.

Mahmudah, L. T. N., \& Indrawati, F. (2015). Analisis Faktor Yang Berhubungan dengan Pemilihan Metode Kontrasepsi Jangka Panjang (MKJP) Pada Akseptor KB Wanita di Kecamatan Banyubiru Kabupaten Semarang. Unnes Journal of Public Health., 4(3), 76-85. https://doi. org/10.15294/ujph.v4i3.7222.

Nurmahdalena, A. (2016). Peran Penyuluhan Keluarga Berencana (PKB) dalam Pengendalian Pertumbuhan Penduduk di Kelurahan Sungau Dama Kecamatan Samarinda Ilir. Jurnal Administrasi Negara, 4(4), 4869-4881.

Reyes-Lacalle, A., Montero-Pons, L., Manresa-Domínguez, J. M., CabedoFerreiro, R., Seguranyes, G., \& Falguera-Puig, G. (2020). Perinatal contraceptive counselling: Effectiveness of a reinforcement intervention on top of standard clinical practice. Midwifery, 83(102631), 1-9. https://doi.org/10.1016/j. midw.2020.102631.

Sharma, A. E., Frederiksen, B. N., Malcolm, N. M., Rollison, J. M., \& Carter, M. W. (2018). Community Education and Engagement in Family Planning: Updated Systematic Review. American Journal of Preventive 
Medicine, 55(5), 747-758. https://doi. org/10.1016/j.amepre.2018.06.022.

Sulikhah, S., Nugroho, D., \& Dharmawan, Y. (2017). Hubungan Beberapa Faktor Pasangan Usia Subur (PUS) Dengan Unmet Need Keluarga Berencana (KB) di Desa Penungkulan Kecamatan Gebang Kabupaten Purworejo Tahun 2016. Jurnal Kesehatan Masyarakat (e-Journal), 5(4), 265-273.

Ulfa, M., \& Yoserizal, H. (2017). Respon Pasangan Usia Subur terhadap Program Keluarga Berencana Gratis di Kelurahan Delima Kecamatan Tampan. Jom Fisip, 4(2), 1-11. Retrieved from https://media. neliti.com/media/publications/199831respon-pasangan-usia-subur-terhadapprog.pdf.

Wowiling, G. J., Pantow, J., \& Waleleng, G. (2015). Komunikasi Informasi dan Edukasi (KIE) sebagai Bentuk Sosialisasi Program Keluarga Berencana (KB) di Kelurahan Tingkulu Kecamatan Wanea Manado. Journal "Acta Diurna," 4(1). 